\title{
Роль Олександра Поля у розвитку середньої освіти Катеринославщини
}

\author{
Прокопенко С. Л., ДП «Науково-дослідний центр «Охоронна археологічна служба України» \\ Інституту археології НАН України
}

Проаналізовано роль Олександра Поля у розвитку середньої освіти Катеринославської губернії в другій половині XIX ст. Висвітлено його діяльність як гласного губернського земства і члена губернської училищної ради у 1866-1872 рр. Охарактеризовані повноваження опікунських рад жіночих гімназій згідно «Положенню про жіночі гімназії і прогімназії відомства Міністерства народної освіти» від 24 травня 1870 р. і показано внесок О. М. Поля як члена опікунської ради Катеринославської Маріїнської жіночої гімназії (1871-1890 рр.) у розвиток навчального закладу і середньої жіночої освіти губернського центру в цілому. Зокрема, окреслено його роль у розвитку матеріальної бази гімназії, що дало змогу протягом 1871-1881 рр. майже в 1,5 рази (з 325 до 486) збільшити чисельність вихованок гімназії і дало поштовх створенню у 1883 р. в Катеринославі Першої міської жіночої гімназії.

3'ясовано коло повноважень почесного попечителя реального училища за «Статутом реальних училищ» від 15 травня 1872 р. і розкрита діяльність О. М. Поля в якості почесного попечителя Катеринославського реального училища, на посаду якого він тричі (у 1882, 1885 і 1888 рр.) обирався на спільних засіданнях губернських земських зборів та Катеринославської міської думи. Показана також діяльність О. М. Поля на посаді голови попечительства Катеринославського реального училища, яку він обіймав до 1888 р. Підсумком стало збільшення кількості учнів в училищі зі 128 у 1880-1881 навчальному році до 215 у $1889-1890$ навчальному році.

Наведено оцінки діяльності О. М. Поля і його внеску у розвиток Катеринославської Маріїнської жіночої гімназії та Катеринославського реального училища авторами нарисів цих навчальних закладів О. Я. Риндовською (Черновою) та С. Ф. Тимощенком, з якими він тривалий час співпрацював.

Ключові слова: О. М. Поль; губернське земство; Катеринославська Маріїнська жіноча гімназія; Катеринославське реальне училище

\section{Oleksandr Pol role in the secondary education development in Ekaterynoslav region}

\section{Prokopenko S. L., State Enterprise "Scientific research center "Protective archeological service of Ukraine» Institute of Archeology of National Academy of Sciences of Ukraine}

The role of Oleksandr Pol (1832-1890), a well-known Ukrainian public and cultural figure, entrepreneur and ethnographer, in the development of secondary education in Katerynoslav province in the second half of the nineteenth century is analyzed. The works of pre-revolutionary and modern researchers, which highlight the activity of O.M. Pol, are described. His activities as a head of the provincial zemstvo and a member of the provincial school council (1866-1872), which was the authority of the national education, created in accordance with the «Regulations on Elementary Schools» of July 14, 1864, are explained. The powers of the Board of Trustees of women's gymnasiums are described in accordance with the «Regulation on women's gymnasia and progymnasia of the Ministry of Education» of May 24, 1870 and the contribution of O.M. Pol as a member of the Board of Trustees of Katerynoslav Mariinsky Women's Gymnasium (1871-1890) in the development of the educational institution and the secondary women education of the provincial center as a whole is shown. In particular, his role in the development of the material base of the gymnasium is outlined, this promoted to increase the number of pupils of the gymnasium in almost 1,5 times (from 325 to 486) during 1871-1881 and gave impetus to the establishment of the First City Women's Gymnasium in 1883 in Katerynoslav.

The range of powers of the honorary trustee of the non-classical secondary school in accordance with the «Statute of the school» determined from May 15, 1872, and the activity of O.M. Pol as an honorary trustee of the Katerynoslav non-classical secondary school, on this post he was elected three times (in 1882, 1885 and 1888) on the joint meetings of the provincial zemstvo assemblies and Ekaterinoslav city duma. O.M. Pol activity as a head of the trusteeship of the Katerynoslav non-classical secondary school, which he occupied until 1888, is described. The result was an increase in the number of pupils in the (in 1882, 1885 and 1888) from 128 persons in the 1880-1881 academic year to 215 persons in the $1889-1890$ academic year.

The article gives estimations of activity O.M. Pol and his contribution to the development of Katerinoslav Mariinsky Women's Gymnasium and Katerynoslav non-classical secondary school made by the authors of the essays of these educational institutions O.Ya. Ryndovska (Chernova) and S.F. Tymoshenko, with whom he worked for a long time.

Keywords: O. M. Pol; province authority; Katerynoslav Mariins'ka women's gymnasium; Katerynoslav non-classical secondary school 


\title{
Роль Александра Поля в развитии среднего образования Екатеринославщины
}

\author{
Прокопенко С. Л., ГП «НИЦ «Охранная археологическая служба Украины» Института архео- \\ логии НАН Украины
}

Проанализирована роль Александра Поля в развитии среднего образования Екатеринославской губернии во второй половине XIX в. Освещена его деятельность в качестве гласного губернского земства и члена губернского училищного совета в 1866-1872 гг. Охарактеризованы полномочия попечительских советов женских гимназий согласно «Положению о женских гимназиях и прогимназиях ведомства Министерства народного просвещения» от 24 мая 1870 и показано вклад А. Н. Поля как члена попечительского совета Екатеринославской Мариинской женской гимназии (1871-1890 гг.) в развитие учебного заведения и среднего женского образования губернского центра в целом. В частности, определено его роль в развитии материальной базы гимназии, что позволило в течение 1871-1881 гг. почти в 1,5 раза (с 325 до 486) увеличить численность воспитанниц гимназии и дало толчок созданию в 1883 г. в Екатеринославе Первой городской женской гимназии .

Выяснено круг полномочий почетного попечителя реального училища согласно «Уставу реальных училищ» от 15 мая 1872 г. и раскрыта деятельность А. Н. Поля в качестве почетного попечителя Екатеринославского реального училища, на должность которого он трижды (в 1882, 1885 и 1888 гг.) избирался на совместных заседаниях губернского земского собрания и Екатеринославской городской думы. Показана также деятельность А. Н. Поля в должности председателя попечительства Екатеринославского реального училища, которую он занимал до 1888 г. Итогом стало увеличение количества учеников в училище со 128 в 1880-1881 учебном году до 215 в 1889-1890 учебном году.

Приведены оценки деятельности А. Н. Поля и его вклада в развитие Екатеринославской Мариинской женской гимназии и Екатеринославского реального училища авторами очерков этих учебных заведений А. Я. Рындовской (Черновой) и С. Ф. Тимощенко, с которыми он долгое время сотрудничал.

ключевые слова: А. Н. Поль; губернское земство; Екатеринославская Мариинская женская гимназия; Екатеринославское реальное училище

\section{Постановка проблеми.}

$\Pi$ оль О. М. (1832-1890) - український громадський i культурний діяч, підприємець і краєзнавець, відомий своїм внеском в економічний та культурний розвиток Катеринославщини, в тому числі і в розвиток освіти.

Аналіз досліджень та публікацій.

Діяльності О. М. Поля присвячено досить широке коло публікацій як дореволюційних (I. Ф. Вертоградов [1], А. С. Синявський [15]), так і сучасних (О. М. Донік [4], І. О. Кочергін [6], В. П. Платонов [11]) дослідників. Всі вони, характеризуючи громадську діяльність О. М. Поля, відзначають, що помітне місце в ній посідали турботи про розвиток освіти нашого краю. Про це писали і автори нарисів навчальних закладів міста (O. Я. Чернова [18], С. Ф. Тимощенко [17]), з якими тривалий час співпрацював О. М. Поль. Проте комплексно роль О. М. Поля у розвитку середньої освіти краю в історіографії не розглядалася.

Метою дослідження $\epsilon$ комплексний аналіз внеску О. М. Поля у розвиток середньої освіти Катеринославщини, висвітлення його діяльності в якості гласного губернського земства, члена опікунської ради Катеринославської Маріїнської жіночої гімназії, почесного попечителя і голови попечительства Катеринославського реального училища.

Виклад основного матеріалу.

Олександр Поль відіграв значну роль у розвит- ку освіти на Катеринославщині. У 1866 р. після створення земств у Катеринославській губернії він як губернський гласний був обраний до першого складу губернської училищної ради і у 1869 p. переобраний на наступний трирічний термін. Губернські училищні ради - органи керівництва початковою школою, створювалися відповідно до «Положення про початкові народні училища» від 14 липня 1864 р. у складі єпархіального архієрея, губернатора, директора училищ губернії і двох представників від губернських земських зборів. До їх функцій належали: вище опікування народними училищами губернії, розгляд звітів повітових училищних рад і подання їх зі своїми зауваженнями попечителю навчального округу, розгляд різноманітних подань повітових рад, призначення допомоги вчителям і школам, розгляд скарг на рішення повітових рад та їх голів, затвердження на посадах обраних голів повітових рад, призначення членів повітових рад зі складу попечителів початкових народних училищ тощо [2, с.617].

Перебуваючи у 1866-1872 рр. членом училищної ради, О. М. Поль фактично ініціював становлення політики губернського земства щодо розвитку народної освіти. Вже на першій, організаційній, сесії губернських земських зборів у вересні 1866 p. він заявив про необхідність визначення основних напрямів діяльності земства в сфері народної освіти, потребу, його словами, «поставити загальне питання про народну освіту» на найближчій сесії земських зборів 


\section{$[13$, c. $336 ; 16$, c. 965$]$.}

Водночас у 1871 р. О. М. Поль був обраний членом опікунської ради Катеринославської Маріїнської жіночої гімназії і залишався на цій посаді до смерті у 1890 р. Згідно «Положення про жіночі гімназії і про гімназії відомства Міністерства народної освіти» від 24 травня 1870 p. на опікунську раду покладалися досить широкі повноваження: обрання попечительки і начальниці гімназії; відшукання коштів для матеріального поліпшення навчального закладу; складання щорічного кошторису витрат гімназії; визначення жалування начальниці та іншим посадовим особам; нагляд за правильним використанням училищних сум; визначення розміру плати за навчання; звільнення від плати за навчання недостатніх учениць; заступництво і допомога найбіднішим ученицям, які відзначаються старанністю і доброзвичайністю; опікування взагалі установленням і постійним збереженням в гімназії належного порядку і благоустрою [3, с. 702].

Опікунська рада гімназії повною мірою виконувала ці завдання, зокрема, вона багато зробила для розвитку матеріальної бази навчального закладу, включаючи ремонт і пристосування у 1865 p. будинку А. С. Понятовського для відкриття гімназії. До 1871 р. в гімназії поступово були відкриті всі класи, в тому числі і VIII педагогічний клас. Кількість учениць суттєво зросла і постала проблема приміщень, оскільки гімназія не могла прийняти всіх бажаючих навчатися, багатьом доводилось відмовляти у прийомі на навчання, що викликало незадоволення батьків. Вихід вбачався у розширенні приміщення гімназії з тим, щоб можна було відкрити паралельні класи. У 1874 p. опікунська рада приступила до будівництва прибудови за рахунок власних коштів, пожертвувань попечительки гімназії М. С. Кох та допомоги міської думи. Але цих коштів (8 тис. крб.) не вистачало для завершення будівництва і в 1876 р. О. М. Поль, як гласний губернського земства, ініціював від імені опікунської ради виділення земськими зборами на завершення будівництва безвідсоткової позики на 10 років у сумі 8 тис. крб. У 1878 p., як зазначала багатолітня начальниця гімназії $\mathrm{O}$. Я. Риндовська (Чернова), «завдяки енергійному і гарячому клопотанню члена опікунської ради О. М. Поля» губернські збори взагалі скасували цей борг [18, с. 8-9, 12].

Завершення у 1877 р. будівництва дало змогу відкрити у 1877-1879 рр. паралельні відділення у I-IV класах. У підсумку чисельність вихованок у гімназії зросла 3325 у 1871 р. до 486 у 1881 р. Проте брак вільних приміщень не давав можливості відкривати паралелі у старших класах. У зв'язку з цим у квітні 1881 р. опікунська рада гімназії звернулася до Катеринославської міської думи з пропозицією відкрити в місті, замість існуючих паралельних відділень Маріїнської гімназії, жіночу прогімназію. Педагогічна рада мотивувала цю пропозицію тим, що в 1880-1881 навчальному році у V-й клас гімназії було прийнято 71 ученицю (при нормативі 40 учениць у класі), при цьому значній частині бажаючих, випускницям Мелітопольської, Новомосковської і Павлоградської прогімназій, було відмовлено. Після тривалого обговорення міська дума у 1882 р. прийняла рішення про відкриття у 1883 р. міської жіночої прогімна3іï. Таким чином, опікунська рада виступила фактично ініціатором створення цього навчального закладу, який з часом став називатися Першою міською жіночою гімназією $[5$, с. $1-2,6 ; 16$, с. 988 ; 18$, c. 8,78$]$.

Ураховуючи внесок О. Я. Риндовської (Чернової) у розвиток жіночої освіти, губернські земські збори у грудні 1889 р. за пропозицією О. М. Поля прийняли рішення заснувати стипендію іï імені на ознаменування 25-річного ювілею керівництва навчальним закладом. Оскільки, згідно височайшому повелінню від 5 грудня 1881 р., міністр народної освіти міг надавати дозвіл на заснування іменних стипендій лише в тому випадку, якщо «ці особи не знаходяться у начальницьких відносинах до навчальних закладів, в яких засновується стипендія», то питання було винесено на розгляд царя і 24 лютого 1890 р. отримано його схвалення про заснування стипендії імені О. Я. Чернової за рахунок відсотків із капіталу в 1900 крб. 2 березня 1890 р. міністром було затверджено і «Положення про стипендію імені начальниці Катеринославської Маріїнської жіночої гімназії Олександри Якимівни Чернової при означеній гімназії». [7; 12; 16, c. 1013].

У 1875 р. у Катеринославі було відкрите реальне училище, яке утримувалося за рахунок коштів казни, катеринославських губернського i повітового земств та міської думи. Згідно «Статуту реальних училищ» від 15 травня 1872 р., Катеринославське губернське земство та міська дума мали обирати почесного попечителя училища як загального представника. У грудні 1882 р. на спільному засіданні губернських земських зборів та міської думи О. М. Поль був обраний почесним попечителем Катеринославського реального училища. У 1885 та 1888 рр. він переобирався почесним попечителем на наступні трирічні терміни. Статут 1872 р. визначав, що почесний попечитель мав стежити за ходом управління і станом реального училища, але не мав робити ніяких розпоряджень, а тільки повідомляти про помічені недоліки безпосереднє керівництво закладу, або ж доводити їх до відома педагогічної ради чи господарського комітету або попечителя навчального округу. Почесному попечителю надавалося право контролю за дійсним і правильним використанням сум, які йдуть від земств, станів, товариств або приватних осіб, на утримання або в допомогу реальному училищу, він брав участь у складанні кошторису i міг у будь-який час перевіряти витрати, здійснені за рахунок пожертвуваних сум. Почесний попе- 
читель міг брати участь у засіданнях педагогічної ради чи господарського комітету училища $[16$, с. 1005-1007; 19, с. 634].

Певна двоїстість прав і обов'язків почесного попечителя спонукала О. М. Поля, разом із рядом інших гласних, у тому числі першим почесним попечителем реального училища П. М. Міклашевським, поставити на сесії губернських земських зборів питання про клопотання перед урядом щодо розширення прав почесних попечителів, зокрема про надання почесному попечителю права вирішального голосу у педагогічній раді. Проте комітет міністрів це клопотання губернських земських зборів відхилив [16, с. 962].

О. М. Поль головував також до 1888 р. у попечительстві реального училища, яке за Статутом 1872 р. мало турбуватися: про складання при училищі колекції місцевих матеріалів і продуктів; про надання учням можливості відвідувати навколишні фабрики, заводи і ферми і взагалі про влаштування екскурсій; про допомоги відмінним учням до продовження навчання в одному з вищих спеціальних навчальних закладів; про влаштування випускників на посади, які відповідають їхній підготовці; про обрання тих нових іноземних мов, які мають викладатися в реальному училищі; про відшукання коштів на облаштування приміщення і для поліпшення викладання [19, с. 634].

Керуючись визначеними у Статуті завданнями, почесні попечителі і попечительство училища вирішували складні питання становлення та розвитку навчального закладу. Катеринославське реальне училище було відкрите спочатку у складі чотирьох класів (III-VI), 3 1880-1881 навчального року відкрився VII-й додатковий клас. У 1882 p. попечительство училища визнало за необхідне відкрити також I і II класи $з$ метою поліпшення рівня підготовки учнів III-го класу. 3 дозволу Державної ради вони були відкриті у 1884 р. На ї облаштування губернські земські збори у грудні 1883 р. за клопотанням О. М. Поля виділили 300 крб. У 1889 р. було відкрите підготовче відділення, на утримання якого губернські земські збори асигнували щорічно по 300 крб. [16, с. 998; 17, с. 26-29].

Відкриття цих класів, побудова у 1891 р. нового, власного приміщення училища (нині корп. 2 ДНУ) дали змогу значно розширити можливості для надання реальної освіти в нашому краї. Якщо в рік відкриття, у 1875-1876 навчальному році, в училищі навчався 31 учень, то у 1880-1881 навчальному році кількість учнів зросла до 128 , в 1885-1886 навчальному році - до 157, у 1889-1890 навчальному році - до 215 учнів, у 1894-1895 році - до 235, а в 1899-1900 навчальному році - до 325. Тобто за перші 25 років існування училища чисельність учнів зросла у 15 разів [17, с. 118$]$.

Що стосується станової належності учнів, то серед них переважали діти дворян і чиновників, які складали $60 \%$, другою групою були міські жи- телі - біля 40\%. Причому в реальному училищі навчалися діти не тільки 3 губернського центру, але й з інших міст та сіл губернії. Так, у 1880-1881 навчальному році 68 учнів були з Катеринослава, 44 з Катеринославської губернії і 21 з інших губерній, у 1882-1883 навчальному році відповідно 64, 36 i 16, у 1886-1887 навчальному році - 101, 26 та $10[8$, с. $30-31 ; 9$, с. $28 ; 10$, с. 30$]$.

Для обладнання кабінету природничих наук О. М. Поль спеціально підібрав і подарував училищу багату колекцію криворізьких руд, яка стала прикрасою кабінету. В училищі з 1885 р. існувала обладнана відповідно до інструкції Головної фізичної обсерваторії метеорологічна станція II розряду, якою тривалий час керував відомий учений I. Я. Акінфієв. Поступово обладнання іï приладами все збільшувалося, і з часом, як за своїм обладнанням, так і за веденням спостережень, вона перетворилася на одну з великих метеорологічних станцій. Існувала станція на кошти Катеринославського губернського земства, яке у 1880-х - на початку 1890-х рр. видавало станції щорічні субсидії - по 300 крб. [17, с. 41, 46].

Оцінюючи діяльність О. М. Поля на посаді почесного попечителя, історик Катеринославського реального училища С. Ф. Тимощенко відзначав: «Олександр Миколайович, як почесний попечитель, завжди 3 особливою увагою ставився до інтересів і потреб училища і в необхідних випадках надавав значне сприяння своїм впливом на місцеве товариство. Повага, якою користувався Олександр Миколайович у середовищі місцевих товариств, і енергійність його натури при повному співчутті навчальному закладу, якого він був почесним попечителем, у багатьох відношеннях принесли немало користі Катеринославському реальному училищу» [17, с. 63].

Заслуги О. М. Поля були оцінені ще за його життя: м. Катеринослав обрало його почесним громадянином, губернське дворянство постановило встановити його портрет у залі Потьомкінського палацу і заснувати стипендію його імені в С.-Петербурзькому гірничому інституті. У 1889 p. дворянство Верхньодніпровського повіту в пам'ять заслуг свого земляка на відсотки з 7000 крб. заснували в Катеринославському реальному училищі стипендію імені О. М. Поля. О. М. Поль, розуміючи необхідність підготовки фахівців гірничої справи для Криворізького басейну, в 1890 р. розробив проект створення гірничого і гірничозаводського училища, але передчасна смерть стала на заваді реалізації цього задуму. У 1897 р. Верхньодніпровські повітові земські збори розглянули цей проект і постановили виділити кошти на відкриття училища ім. О. М. Поля в Кривому Розі та видали його програму. Ідею підтримав XXII з'їд гірничопромисловців Півдня Росії (1897), пожертвувавши на облаштування училища 100 тис. крб [14, с 49; 15, с. XXIX; 17, с. 59].

На завершення хотілося б навести ще одну 
оцінку особистості О. М. Поля - одного з перших дослідників його діяльності А. С. Синявського. Він писав, що, без сумніву, Олександр Миколайович «був силою величезного громадського су- спільного значення, людиною хороших ідей і неухильного їм служіння». І це добре помітно на тому внеску, який він зробив у розвиток освіти нашого краю [15, с. XXIII].

\section{БІБІЛІОГРАФІЧНІ ПОСИЛАННЯ}

1. Вертоградов И. Ф. Памяти А. Н. Поля (По поводу 20-ти летия со дня его смерти) / И. Ф. Вертоградов. - Екатеринослав, 1910. $-27 \mathrm{c}$.

2. Высочайше утвержденное Положение о начальных народных училищах: именной указ, данный Правительствующему Сенату 14 июля 1864 года // Полное собрание законов Российской империи (далее - ПСЗРИ). - Собр. 2. - СПб, 1867. - Т.XXXIX. - Отд. 1. - С. 613-618.

3. Высочайше утвержденное Положение о женских гимназиях и прогимназиях ведомства Министерства народного просвещения 24 мая 1870 г. // ПСЗРИ. - Собр. 2. - СПб, 1874. - Т. XLV. - Отд. 1. - С. 701-705.

4. Донік О. М. Поль Олександр Миколайович / О. М. Донік // Енциклопедія історії України: [у 10 т.]. - Київ: Наук. думка, 2011. - Т. 8: Па - Прик. - С. 378.

5. Донцов Г. В. Десятилетие Екатеринославской городской женской гимназии 1883-1893 / Г. В. Донцов. - Екатеринослав, 1894. $-47 \mathrm{c}$.

6. Кочергін І. Олександр Поль: мрії, справи, спадщина / І. Кочергін. - Дніпропетровськ: НГАУ, 2002. - 222 с.

7. Об учреждении при Екатеринославской Мариинской женской гимназии стипендии имени начальницы сей гимназии А. А. Черновой: высочайшее повеление от 24 февраля 1890 г. // Сборник постановлений по Министерству народного просвещения. - СПб, 1895. - Т. 11. 1889-90 гг. - с. 1106.

8. Отчет о состоянии Екатеринославского реального училища в 1880-1881 учебном году. - Екатеринослав, 1882 - 31 с.

9. Отчет о деятельности и состоянии Екатеринославского реального училища за 1882-83 учебный год. - Екатеринослав, $1883-32 \mathrm{c}$.

10. Отчет о состоянии Екатеринославского реального училища в педагогическом и материальном отношении за $1886-$ 1887 учебный год. - Екатеринослав, 1887 - 34 с.

11. Платонов В. Человек-легенда: Александр Поль / В. Платонов. - Днепропетровск: Проспект, 2002. - 208 с.

12. Положение о стипендии имени начальницы Екатеринославской Мариинской женской гимназии Александры Акимовны Черновой при означенной гимназии: распоряжение министра народного просвещения от 2 марта 1890 г. // Журнал Министерства народного просвещения. - март 1890. - Ч. CCLXVIII. - C. 23-24.

13. Постановления очередного Екатеринославского губернского земского собрания. Ноябрьской сессии 1867 года. Екатеринослав, 1868. - $601 \mathrm{c}$.

14. Прокопенко Л. Л. Становлення та розвиток системи підготовки гірничих кадрів в Україні у XIX - на початку XX ст. / Л. Л. Прокопенко, Т. Д. Прокопенко // Гуманітарний журнал. - 2005. - № 3. - С. 45-51.

15. Синявский А. А. Н. Поль (Биографический очерк к открытию здания музея его имени) / А. Синявский // Летопись Екатеринославской Ученой Архивной Комиссии. Год первый. - Екатеринослав, 1904. - С. XIII-XXXIV.

16. Систематический свод постановлений Екатеринославского губернского земского собрания 1866-1913 г.г.: составлен под редакцией П. К. Соколова. - Екатеринослав, 1914. - Т. 1: 1866-1889 г. - 1177 с.

17. Тимощенко С. Исторический очерк Екатеринославского реального училища за двадцать пять лет его существования 1875-1900 / С. Тимощенко. - Екатеринослав, 1901. - 144 с.

18. Чернова А. А. Историческая записка о Екатеринославской Мариинской женской гимназии со времени ее основания по 1 августа 1881 года / А. А. Чернова. - Екатеринослав, 1883 - 109 с.

19. Устав реальных училищ, высочайше утвержденный 15 мая 1872 г. // ПСЗРИ. - Собр. 2. - СПб, 1875. - T. XLVII.- Отд. 1. - C. 626-636.

\section{REFERENCES}

1. Vertogradov, I.F. (1910). Pamiati A.N. Polia (Po povodu 20-ti letiia so dnia ego smerti) [In memory of A.N. Pol (In occasion of the 20th anniversary of his death)]. Ekaterinoslav [in Russian].

2. Vysochaishe utverzhdennoe Polozhenie o nachalnykh narodnykh uchilishchakh: imennoi ukaz, dannyi Pravitelstvuiushchemu Senatu 14 iiulia 1864 goda [The highest approved Statute of primary public schools: a nominal decree given to the Government Senate on July 14, 1864]. (1867). Polnoe sobranie zakonov Rossiiskoi imperii), 2 (XXXIX), 613-618. SPb [in Russian].

3. Vysochaishe utverzhdennoe Polozhenie o zhenskikh gimnaziiakh i progimnaziiakh vedomstva Ministerstva narodnogo prosveshcheniia 24 maia $1870 \mathrm{~g}$. [Highest approved Regulations on women's gymnasiums and progymnasiums of the Ministry of Education on May 24, 1870]. (1874). Polnoe sobranie zakonov Rossiiskoi imperii), 2 (XLV), 701-705. Spb [in Russian].

4. Donik, O.M. (2011). Pol' Oleksandr Mykolayovych. Entsyklopediya istoriyi Ukrayiny. (Vols. 1-10). Kyiv: Nauk. Dumka [in Ukrainian].

5. Dontcov, G.V. (1894). Desiatiletie Ekaterinoslavskoi gorodskoi zhenskoi gimnazii 1883-1893 [Decade of the Ekaterinoslav City Women's Gymnasium 1883-1893]. Ekaterinoslav [in Russian].

6. Kocherhin, I. (2002). Oleksandr Pol': mriyi, spravy, spadshchyna [Alexander Pol: dreams, affairs, heritage]. Dnipropetrovsk: NHAU [in Ukrainian]. 
7. Ob uchrezhdenii pri Ekaterinoslavskoi Mariinskoi zhenskoi gimnazii stipendii imeni nachalnitcy sei gimnazii A.A. Chernovoi: vysochaishee povelenie ot 24 fevralia 1890 g. [7. On the establishment of the Ekaterinoslav Mariinsky Women's Gymnasium scholarship named after the head of this gymnasium A. A. Chernova: the highest command of February 24, 1890]. (1895). Sbornik postanovlenii po Ministerstvu narodnogo prosveshcheniia. (Vol. 11). SPb [in Russian].

8. Otchet o sostoianii Ekaterinoslavskogo realnogo uchilishcha v 1880-1881 uchebnom godu [Report on the state of the Ekaterinoslav Real School in the 1880-1881 school year]. (1882). Ekaterinoslav [in Russian].

9. Otchet o deiatelnosti $i$ sostoianii Ekaterinoslavskogo realnogo uchilishcha za 1882-83 uchebnyi god [9. Report on the activities and status of the Ekaterinoslav Real School for the 1882-83 academic year]. (1883). Ekaterinoslav [in Russian]. 10. Otchet o sostoianii Ekaterinoslavskogo realnogo uchilishcha v pedagogicheskom i materialnom otnoshenii za $1886-$ 1887 uchebnyi god [Report on the state of the Ekaterinoslav Real School in pedagogical and material terms for the 1886 1887 academic year]. (1887). Ekaterinoslav [in Russian].

11. Platonov, V. (2002). Chelovek-legenda: Aleksandr Pol [Man-legend: Alexander Paul]. Dnipropetrovsk: Prospekt [in Russian].

12. Polozhenie o stipendii imeni nachalnitcy Ekaterinoslavskoi Mariinskoi zhenskoi gimnazii Aleksandry Akimovny Chernovoi pri oznachennoi gimnazii: rasporiazhenie ministra narodnogo prosveshcheniia ot 2 marta 1890 g. [Regulations on the scholarship grant of the head of the Ekaterinoslav Mariinsky Women's Gymnasium Alexandra Akimovna Chernova at the indicated gymnasium: the order of the Minister of Education on March 2, 1890]. (1890). Zhurnal Ministerstva narodnogo prosveshcheniia, CCLXVIII, 23-24 [in Russian].

13. Postanovleniia ocherednogo Ekaterinoslavskogo gubernskogo zemskogo sobraniia. Noiabrskoi sessii 1867 goda [Decisions of the next Ekaterinoslav Provincial Zemsky Assembly. November session of 1867]. (1868). Ekaterinoslav [in Russian].

14. Prokopenko, L.L., \& Prokopenko, T.D. (2005). Stanovlennya ta rozvytok systemy pidhotovky hirnychykh kadriv v Ukrayini u XIX - na pochatku XX st. [Formation and development of the mining personnel training system in Ukraine in the 19th and early 20th centuries]. Humanitarnyy zhurnal, 3, 45-51 [in Ukrainian].

15. Siniavskii, A. (1904). A.N. Pol (Biograficheskii ocherk k otkrytiiu zdaniia muzeia ego imeni) [A.N. Pol (Biographical sketch for the opening of the building of the museum of his name)]. Letopis Ekaterinoslavskoi Uchenoi Arkhivnoi Komissii. God pervyi. Ekaterinoslav [in Russian].

16. Sokolov, P.K. (Eds.). (1914). Sistematicheskii svod postanovlenii Ekaterinoslavskogo gubernskogo zemskogo sobraniia 1866-1913 g. [A systematic set of resolutions of the Ekaterinoslav Provincial Zemsky Assembly of 1866-1913]. Ekaterinoslav [in Russian].

17. Timoshchenko, S. (1901). Istoricheskii ocherk Ekaterinoslavskogo realnogo uchilishcha za dvadtcat piat let ego sushchestvovaniia 1875-1900 [A historical sketch of Ekaterinoslav's real school for twenty-five years of its existence 1875-1900]. Ekaterinoslav [in Russian].

18. Chernova. A.A. (1883). Istoricheskaia zapiska o Ekaterinoslavskoi Mariinskoi zhenskoi gimnazii so vremeni ee osnovaniia po 1 avgusta 1881 goda [Historical note on the Ekaterinoslav Mariinsky Women's Gymnasium from the time of its foundation to August 1, 1881]. Ekaterinoslav [in Russian].

19. Ustav realnykh uchilishch, vysochaishe utverzhdennyi 15 maia $1872 \mathrm{~g}$. [The charter of real schools, supreme approved on May 15, 1872]. (1875). Polnoe sobranie zakonov Rossiiskoi imperii, 2 (XLVII), 626-636. SPb [in Russian].

\section{Прокопенко Сергій Леонідович}

Молодший науковий співробітник

ДП «Науково-дослідний центр «Охоронна археологічна служба України» Інституту археології НАН України 04210, м. Київ, просп. Героїв Сталінграда, 12

\section{Prokopenko Sergii L.}

Senior scientific employee

State Enterprise «Scientific research center «Protective archeological service of Ukraine» Institute of Archeology of National Academy of Sciences of Ukraine

12, Heroiv Stalinhrada Ave., 04210, Kyiv, Ukraine

ORCID: 0000-0002-6273-6959 Email: badaboom1510@gmail.com

Цитування: Прокопенко С. Л. Роль Олександра Поля у розвитку середньої освіти Катеринославщини / С. Л. Прокопенко // Науково-теоретичний альманах «Грані». - 2018. - Т. 21. - № 4. - С. 12-17.

Citation: Prokopenko, S.L. (2018). Rol Oleksandra Polia u rozvytku serednoi osvity Katerynoslavshchyny [Oleksandr Pol role in the secondary education development in Ekaterynoslav region]. Scientific and theoretical almanac «Grani», 21(4), 12-17. 